\title{
Loricate choanoflagellates (Acanthoecida) from warm water seas. III. Acanthocorbis Hara and Takahashi and Stephanoeca Ellis
}

\section{Thomsen, Helge Abildhauge; Østergaard, Jette Buch}

\section{Published in:}

European Journal of Protistology

Link to article, DOI:

10.1016/j.ejop.2019.02.001

Publication date:

2019

Document Version

Peer reviewed version

Link back to DTU Orbit

\section{Citation (APA):}

Thomsen, H. A., \& Østergaard, J. B. (2019). Loricate choanoflagellates (Acanthoecida) from warm water seas. III. Acanthocorbis Hara and Takahashi and Stephanoeca Ellis. European Journal of Protistology, 69, 52-69. https://doi.org/10.1016/j.ejop.2019.02.001

\section{General rights}

Copyright and moral rights for the publications made accessible in the public portal are retained by the authors and/or other copyright owners and it is a condition of accessing publications that users recognise and abide by the legal requirements associated with these rights.

- Users may download and print one copy of any publication from the public portal for the purpose of private study or research.

- You may not further distribute the material or use it for any profit-making activity or commercial gain

- You may freely distribute the URL identifying the publication in the public portal 


\section{Accepted Manuscript}

Title: Loricate choanoflagellates (Acanthoecida) from warm water seas. III. Acanthocorbis Hara and Takahashi and Stephanoeca Ellis

Authors: Helge Abildhauge Thomsen, Jette Buch Østergaard

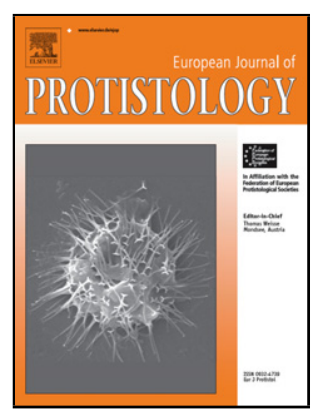

PII:

S0932-4739(18)30137-8

DOI: https://doi.org/10.1016/j.ejop.2019.02.001

Reference: EJOP 25613

To appear in:

Received date: $\quad 14$ December 2018

Revised date: 29 January 2019

Accepted date: $\quad 4$ February 2019

Please cite this article as: Thomsen, Helge Abildhauge, Østergaard, Jette Buch, Loricate choanoflagellates (Acanthoecida) from warm water seas.III.Acanthocorbis Hara and Takahashi and Stephanoeca Ellis.European Journal of Protistology https://doi.org/10.1016/j.ejop.2019.02.001

This is a PDF file of an unedited manuscript that has been accepted for publication. As a service to our customers we are providing this early version of the manuscript. The manuscript will undergo copyediting, typesetting, and review of the resulting proof before it is published in its final form. Please note that during the production process errors may be discovered which could affect the content, and all legal disclaimers that apply to the journal pertain. 
Loricate choanoflagellates (Acanthoecida) from warm water seas. III. Acanthocorbis Hara and Takahashi and Stephanoeca Ellis

Helge Abildhauge Thomsen ${ }^{\mathrm{a},}{ }^{,}$, Jette Buch $\varnothing$ stergaard $^{\mathrm{b}}$

aTechnical University of Denmark, National Institute of Aquatic Resources (DTU Aqua), Kemitorvet, Bygning 201, DK 2800 Kgs. Lyngby, Denmark / hat@aqua.dtu.dk

${ }^{\mathrm{b}} \mathrm{N} \varnothing$ rrebrogade 52a 5th, 2200 Copenhagen N, Denmark

Corresponding author.

E-mail address: hat@aqua.dtu.dk (H.A. Thomsen)

\begin{abstract}
A large-scale investigation of warm water loricate choanoflagellate communities has revealed the presence of close to 80 species, which is approximately half of all loricate choanoflagellate taxa described when including also hitherto undescribed forms known to us. We are in the process of stepwise providing a monographic treatment of these communities. The overall aim is to contribute the best possible account of species diversity, based on traditional light and electron microscopical techniques, as a tool for future identification work based on microscopy, and in support of the work in progress with establishing a quality assured molecular tool for future recognition of diversity. In this paper we summarize our findings of species of Acanthocorbis and Stephanoeca, which include the description of several new taxa: A. conicella sp. nov., A. gladiella sp. nov., S. broomia sp. nov., S. naja sp. nov., and S. andemanica sp. nov.
\end{abstract}


Keywords: Acanthocorbis; Acanthoecida; Loricate choanoflagellates; Stephanoeca; Warm water seas

\section{Introduction}

In an attempt to further our understanding of global diversity patterns, and also in order to update the global species catalogue of loricate choanoflagellates by introducing a large number of hitherto undescribed forms, we are currently in the process of publishing an inventory of warm water species encountered in samples from all major oceans. This is the third paper in the series (Thomsen and Østergaard, 2018, 2019) and the focus is here on species of Acanthocorbis Hara and Takahashi, 1984, and Stephanoeca Ellis, 1929. Leadbeater (2015) defines four groups of species ('themes') that each share certain lorica features and ecological preferences. The 'Stephanoeca' theme thus encompasses forms that are relatively small and yet with a large number of costal strips. The lorica is typically divided by a waist into two chambers, i.e. a small posterior chamber that houses the protoplast, and a larger, typically bulbous chamber, that surrounds the protoplast, collar microvilli and the flagellum. The lorica is a two-layered structure with the longitudinal costae to the outside. Aside from discussing variable degrees of lorica complexity across a range of species of Stephanoeca, Leadbeater (2015) also discusses the fact that a species such as Acanthocorbis apoda (Leadbeater, 1972)Hara and Takahashi, 1984, has much in common with Stephanoeca, except for the fact that an anterior transverse ring is not found in Acanthocorbis. The generalized ecological trademark of the genus Stephanoeca (and Acanthocorbis) is that of a preference for coastal habitats that has much to offer e.g. in terms of nutrients, food items, and surfaces that the organisms can attach to. However, some of the species examined here, e.g. Acanthocorbis haurakiana Thomsen, 1991, and Stephanoeca naja sp. nov., do not exactly comply with the 'near coastal' concept but are rather predominantly oceanic forms.

Additional arguments in favour of treating Stephanoeca and Acanthocorbis in the same document, is the fact that Acanthocorbis (A. unguiculata) closely links with species of Stephanoeca in the molecular phylogeny prepared by e.g. Schiwitza et al. (2018), and further that a possibility exists that these genera are linked together in life cycles and with a possibility of switching pairwise from one lorica type to the other (Thomsen and Østergaard, 2017a). Two versions of a so-called combination lorica, i.e. an empty Acanthocorbis lorica at 
the bottom and on top and attached to this a living Stephanoeca cell (A. campanula/S. apheles and $A$. haurakiana/S. cauliculata) have been repeatedly and consistently observed in Greenland and Danish waters respectively (Thomsen and Østergaard, 2017a).

Here we report on the occurrence of the 12 species (six from each of the two genera) found during our light and electron microscopical search through material collected from warm water habitats.

\section{Material and Methods}

The material that constitutes the background for this and a series of forthcoming papers on warm water acanthoecid choanoflagellates was collected over a period of 35 years. The geographic origin of samples is recorded in Fig. 1. See Thomsen and $\varnothing$ stergaard (2018) for information on each of the collection sites and sampling campaigns.

The general protocol for processing water samples for the light microscope (LM) and transmission electron microscope (TEM) was according to Moestrup and Thomsen (1980). For details on sample processing, preparational issues and microscopes used see Thomsen and $\varnothing$ stergaard (2018).

The material examined here is dried which means that the natural 3-D structures have collapsed to become 2-D structures leading to an artefactual expansion of in particular the lorica width. While several structures can still be measured with confidence, e.g. lorica chamber height and the length of spines and pedicels, it does imply that certain values such as lorica diameter, typically at the level of the transverse costa(e), cannot be measured directly buy only calculated from measurements of the circumference. This approach has been taken in the species descriptions below.

Efforts are made to make use of a concise terminology when describing lorica features and we follow the standards that have developed in the course of dealing with these organisms; see e.g. Leadbeater (2015; loc. cit. chapter 4 and glossary p. 278) and Thomsen and Buck (1991). 


\section{Results and Discussion}

Acanthocorbis Hara and Takahashi, 1984

Syn.: Acanthoecopsis Norris, 1965

The genus currently comprises 12 species and the generic type is $A$. apoda (Leadbeater, 1972)Hara and Takahashi, 1984. Characteristic features of the genus are prominent anterior spines (projections) and a broadly conical lorica. Longitudinal costae are exterior to transverse elements. The protoplast is located at the posterior lorica end and is in Acanthocorbis core species (A. apoda and e.g. A. asymmetrica (Thomsen, 1979)Hara and Takahashi, 1984, A. camarensis Hara, 1996) encased within a chamber that comprises also helical costal elements in addition to transverse and longitudinal costae. A short pedicel is present in some species, i.e. A. asymmetrica, A. campanula (Espeland, 1986)Thomsen, 1991 and A. haurakiana Thomsen, 1991. In A. prolongata Thomsen, Garrison and Kosman, 1997, the stalk is a conspicuous long line of costal strips terminated by a hold-fast tuft of costal strips (Thomsen et al., 1997). Only two species have been sequenced so far, i.e. A. unguiculata (Thomsen, 1973)Hara and Takahashi, 1984, and A. nana Thomsen, Garrison and Kosman, 1997. The molecular results supported the transfer of $A$. nana to the Acanthoecidae as Helgoeca nana (Leadbeater et al., 2008). Based on the heterogenous appearance of the species clustered within the genus Acanthocorbis it must be anticipated, once more molecular data become available, that the genus as presently circumscribed is polyphyletic.

\section{A. apoda (Leadbeater, 1972)Hara and Takahashi, 1984 (Fig. 2a)}

A fairly standard A. apoda (Fig. 2a / lorica height: $15.5 \mu \mathrm{m}$; diam. anterior transverse costa: $12.4 \mu \mathrm{m}$; diam. posterior transverse costa: $6.2 \mu \mathrm{m}$ ) was found in samples from the Andaman Sea (Table 1). The species is frequently reported from temperate and subarctic Atlantic Ocean coastal sites, but also observed in samples from e.g. the Mediterranean Sea (Leadbeater, 1973, 1974) California (Thomsen et al., 1991), Australia (Sydney / Tong et al., 1998), New Zealand (Kaikoura / Moestrup, 1979), and Japan (Lake Saroma / Takahashi, 
1981). The distributional fingerprint of this species is thus a preference for middle latitude locations on both hemispheres and an avoidance of Arctic, Antarctic and tropical habitats.

\section{A. conicella sp. nov. (Fig. 2b-I)}

Diagnosis: Lorica conical and with an overall lorica height of 11.5-14.5 $\mu \mathrm{m}$. There are 11 exteriorly located longitudinal costae each comprising 3 costal strips (5.5-7.5 $\mu \mathrm{m}$ long) and two transverse costae. One transverse costa (diam. 8-10 $\mu \mathrm{m}$ ) is located at the joints between the two anterior longitudinal costal strips. There are 11 transverse costal strips (4.5-6 $\mu \mathrm{m}$ long) that each span the distance between 3 longitudinal costae, thus overlapping its neighbour by half a costal strip. The posterior transverse costa has a diameter of 3-5 $\mu \mathrm{m}$. The protoplast (ca. $3 \times 5 \mu \mathrm{m}$ ) is placed posteriorly and surrounded by the converging longitudinal costae and also apparently a helical costal element. The single flagellum reaches beyond the anterior opening of the lorica and is proximally surrounded by a ring of microvilli. A membrane supporting the attachment of the protoplast to the lorica reaches up to the anterior transverse costa.

Holotype: Fig. $2 \mathrm{c}$ found in a surface water sample (ca. $18^{\circ} \mathrm{C} / 35 \mathrm{PSU}$ ) from a near coastal site at Bahia de los Ángeles, the Gulf of California, collected 7 January 1990.

Etymology: The species epithet 'conicella', meaning a small cone, reflects the straight-sided outer shape of the $A$. conicella lorica.

Acanthocorbis conicella is closely similar to A. apoda (Fig. 2a). The main differences are the presence in $A$. apoda of a more complex and multi-layered anterior transverse costa, and also the fact that in $A$. apoda the anterior transverse costa diameter is proportionally significantly larger than the posterior transverse costa, causing the $A$. apoda lorica to have a pronounced wavy exterior lorica contour, versus a straight-sided appearance in $A$. conicella. Further it should be emphasized that in A. apoda the anterior spines clearly 
exceed the length of one costal strip (while equal to the length of one costal strip in A. conicella) and that the A. apoda longitudinal costa comprises 4 costal strips (only 3 in A. conicella).

Acanthocorbis conicella also resembles $A$. campanula (see below). The two species have similar lorica contours and also show great similarity in the elaboration of the anterior transverse costa, i.e. costal strips that exactly span the width between every third longitudinal costa, and a pattern of interconnections with longitudinal costae that creates very distinct triangular spaces between overlapping transverse costal strips (Fig. 2 B-D). Table 2 summarizes morphometric data for the Norwegian A. campanula type material (Espeland and Throndsen, 1986), material of A. campanula reported here (Fig. 3), and the Gulf of California material of A. conicella (Fig. 2b-d).

The main difference between the $A$. campanula type material and $A$. conicella cells encountered here is the layout of the posterior transverse costa which in the former is a simple circular structure formed by 5-6 costal strips which are perpendicular to the longitudinal costae. In A. conicella the posterior lorica end is more elaborate and consistently comprises a somewhat irregular meshwork of longitudinal and transverse costal strips that form a protective hemisphere around the protoplast. Minor differences also exist in the number of longitudinal costae (11 versus 8-10), the diameter at the level of the anterior transverse costa (the Norwegian A. campanula loricae are significantly narrower and cone-shaped), and with respect to the length of the anterior spines.

An LM recognition of the species is possible as exemplified by Fig. 2e-I.

Acanthocorbis conicella is found in samples from West Australia, the Sargasso Sea, Gulf of California, and the eastern Mediterranean Sea (Table 1).

\section{A. camarensis Hara, 1996 in Hara et al., 1996 (Fig. 2m)}

The specimen illustrated here (Fig. $2 \mathrm{~m}$ ) from the Andaman Sea is identical to A. camarensis with respect to overall lorica dimensions and the presence of very conspicuous anterior projections that each comprises two costal strips. There is one transverse costa and a posterior lorica chamber formed by longitudinally and 
spirally organized costal strips. The main difference between the cell illustrated here and the type material (from Hawaii) is the presence in our material of a larger number of longitudinal costae (18) than reported for the type material (10-14; Hara et al., 1996). Features distinguishing A. camarensis from A. apoda (Fig. 2a) are primarily the longer projections, and a shorter distance between the anterior transverse costa and the lorica waist.

Acanthocorbis camarensis is previously reported from coastal waters of Taiwan, Hawaii, and Thailand (Hara et al., 1996), and from Darwin, Australia (Lee et al., 2003). Here we report A. camarensis from the Andaman Sea only.

\section{A. campanula (Espeland, 1986)Thomsen, 1991 in Thomsen et al., 1991 (Fig. 3)}

The specimens illustrated in Fig. 3a-b,e-f are all characterized by prominent anterior spines, ca. 9 longitudinal costae ( 3 costal strips each) and two transverse costae. There are as many anterior transverse costal strips as there are longitudinal costae. Neighbouring costal strips overlap to a varying degree. The posterior transverse costa comprises 3-5 costal strips. A reduced number of longitudinal costae adjoin posteriorly with a pedicel formed by a single costal strip. There are no additional costal strips, e.g. helical components, in the posterior lorica end. Two of the specimens illustrated here (Fig. 3b,e) have a minute nailshaped termination of the anterior longitudinal costal strips (Fig. 3c). In the two other specimens illustrated from TEM (Fig. 3 a,f) the anterior costal strip termination is rounded and without special features. The significance of this observation is unclear. However, a claw-like termination is considered a diagnostic feature of $A$. unguiculata (Thomsen, 1973). The membrane that supports the protoplast reaches up to the anterior transverse costa. The membrane is best seen in Fig. $3 \mathrm{~b}$ where the lorica background below the anterior transverse costa differs from the surroundings. Longitudinal costal elements are positioned exteriorly. For lorica dimensions etc. see Table 1. There is a solid morphometric agreement between the cells examined 
here and the A. campanula type material. As is evident from Fig. $3 g-j$ this species is assuredly recognized in LM preparations. Fig. 3d verifies that tectiform division takes place in this species.

Acanthocorbis campanula has previously been recorded from Kilsfjorden, Norway (Espeland and Throndsen, 1986), Denmark (Thomsen, 1992; Thomsen et al., 2016), Southampton Water, UK (Tong 1997a), West Greenland (Thomsen and Østergaard, 2017b), Gulf of St Lawrence, Canada (Bérard-Therriault et al., 1999), Rhode Island, USA (Menezes, 2005), California, USA (Thomsen et al., 1991), Japan (Hara and Takahashi, pers. comm.), New Zealand (Moestrup, pers. comm.). Here we report the species from the Andaman Sea, West Australia and the Sargasso Sea (Table 1).

A. haurakiana Thomsen, 1991 in Thomsen et al., 1991 (Fig. 4)

The specimens illustrated in Fig. 4 are in complete agreement with the Californian type material (Thomsen et al., 1991). The most characteristic features of this relatively large species are the 6-7 long and tapering anterior spines, the nest-like configuration of costal strips that supports the protoplast (Fig. 4e-f), and the presence of a conspicuous pedicel that in our material typically comprises two costal strips. It is evident from the illustrations provided here (Fig. 4c-h) that A. haurakiana is easily recognized in LM preparations. The affiliation of $A$. haurakiana with the genus Acanthocorbis will remain uncertain until appropriate molecular tools have been applied to Acanthocorbis species at large. Leadbeater (2015) lists A. haurakiana as a member of the 'Bicosta/Calliacantha' theme and mentions that $A$. haurakiana shares with species otherwise referred to this theme, the presence of anterior and posterior spines. Without ruling out any possibilities with respect to unresolved phylogenetic relationships among loricate species, we must emphasize that the species morphologically most similar to A. haurakiana are represented by species such as A. campanula (Fig. 3f) and in particular A. conicella (Fig. 2b-d) and A. gladiella (Fig. 5).

Acanthocorbis haurakiana is in addition to the Californian type locality previously recorded from the Adriatic Sea and the Bay of Algiers (Leadbeater, 1973, 1974), Southampton Water, UK (Tong 1997a), Denmark 
(Thomsen, 1992; Thomsen and Østergaard, 2017a), the Baltic Sea, Finland (Ikävalko and Thomsen, 1997), Leigh, New Zealand (Thomsen et al., 1991), and Sydney, Australia (Tong et al., 1998). Here we report the species from the Andaman Sea, West Australia, and the Sargasso Sea (Table 1).

\section{A. gladiella sp. nov. (Figs 5-6)}

Diagnosis: Protoplast ca. $3 \times 5 \mu \mathrm{m}$ with a collar of microvilli and a single flagellum up to $10 \mu \mathrm{m}$ long. The protoplast is located in a lorica (13-16 $\mu \mathrm{m}$ long; Fig. $5 \mathrm{~b}-\mathrm{c})$ that has 6 longitudinal costae forming conspicuous spines anteriorly, a single anterior transverse costa (diameter 5-8 $\mu \mathrm{m}$ ) which crosses the anterior longitudinal costal strips at their broadest point (Fig. 6a) and slightly in front of the posterior termination of these (Fig. $6 a$, arrows), and a posterior lorica chamber shaped as a nest-like structure that supports the protoplast. The 'nest' comprises longitudinal, transverse and helical costal strip components. The lorica has a pedicel which is a single costal strip that extends from the posterior tip of the lorica. Longitudinal costae are exterior to other lorica components. A longitudinal costa comprises 3 costal strips, one of which (the anterior spine) is significantly larger (7.5-8.5 $\mu \mathrm{m})$ than the others, tapering to a needle-like point anteriorly, and also furnished with lateral flanges that are presumed to give the costal strip a triradiate cross section (Figs 5a, 6a). Anterior transverse costal strips are 3.4-4.2 $\mu \mathrm{m}$ long, flattened and with 'hilly' lumps of material on the forward edge (Figs 5e, 6a). Costal strips elsewhere (i.e. those forming the 'nest-like' structure) are not typical rod-shaped costal strips, but slightly flattened and battered and often with uneven edges (Fig. 6b). A lorica membrane is present in the posterior part of the lorica and reaches up to the level of the anterior transverse costa (Fig. 5d). The division mode has not been verified.

Holotype: Fig. 5b from the Andaman Sea collected March 1996 at \#31 from a depth of $5 \mathrm{~m}$ (ca. $28^{\circ} \mathrm{C}$ and a salinity of 35 PSU). \#31 is ca. $100 \mathrm{~km}$ offshore and at a total depth of ca. $200 \mathrm{~m}$ (Nielsen et al., 2004; loc.cit. Fig. 1).

Etymology: The species epithet 'gladiella' is derived from 'gladius' (L) meaning sword and -ella (diminutive) and chosen because the anterior longitudinal spines are reminiscent of swords. 
Acanthocorbis gladiella is a unique loricate choanoflagellate species because of the elaborate design of in particular the anterior spines. Based on the material available these are interpreted as being triradiate in cross section and with flanges extending almost the entire length of the costal strip (Fig. 5a, 6a (arrowheads)).

The new species described here has been allocated to the genus Acanthocorbis primarily because of a striking resemblance in overall lorica design between this species and A. haurakiana (Fig. 4). However, no other species of Acanthocorbis have costal strip modifications as described above for A. gladiella. Within classical morphology-based taxonomy it has become a habit to separate species with elaborate costal strip morphology into self-contained genera (e.g. Platypleura and Stephanacantha; Thomsen and Boonruang, 1983) even though from a purely lorica constructional perspective species allocated to these genera often completely match other choanoflagellate species with 'normal' rod-shaped costal strips. In order not to anticipate events and in view of the expected polyphyletic nature of the cluster of Acanthocorbis species currently described, it seems best to take a conservative approach and use the link between $A$. haurakiana and $A$. gladiella to secure an interim placing of our new species. It should be emphasized that a second option has also been considered. Acanthocorbis gladiella shares with Saroeca attenuata Thomsen, 1979, the presence of unusually long and tapering anterior spines in which the anterior transverse costa crosses where these strips have their maximum width, slightly in front of their posterior tip (Thomsen, 1979). However, the elaboration of the posterior lorica end is in A. gladiella much more similar to A. haurakiana which tipped the scale in favour of making use of the genus Acanthocorbis rather than Saroeca.

The recognition of $A$. gladiella in the LM (Fig. $5 \mathrm{f}-\mathrm{i}$ ) is possible in most cases. The best diagnostic features are the wide anterior spines and the 'nest-shaped' configuration of the posterior part of the lorica.

We report here A. gladiella from the Andaman Sea, West Australia, the equatorial Pacific Ocean, the Caribbean Sea, and the Sargasso Sea (Table 1).

Stephanoeca Ellis, 1929 
Species of Stephanoeca are characterized by a small lorica that is differentiated into a posterior lorica chamber, which encompasses the protoplast, and a larger anterior lorica chamber separated by a distinct waist. There are numerous costal strips organized in a two-layered set up with longitudinal costae to the outside and transverse or helical costal strips forming an inside layer. The latter are typically organized as a series of transverse costae in the anterior lorica chamber and helical costae in the posterior lorica chamber. The Stephanoeca lorica is particularly vulnerable to become disorganized when processed for microscopy. Leadbeater (2015) thus discusses how e.g. drying impacts on the physical appearance of the lorica components (Leadbeater, 2015; I.c. Fig. 4.54) and in particular the costal strip configuration at the anterior orifice of the lorica. Drying also significantly changes the appearance of the posterior chamber helical costae resulting in the appearance of the lorica chamber as a nest-like and irregular collection of costal strips.

The genus as currently circumscribed comprises close to 20 species (Table 3) that are distinguished e.g. by the number of transverse costae in the anterior chamber and the placement of these, by the overall lorica complexity in terms of the number of costal strips involved (e.g. S. norrisii Thomsen, 1973, which has in excess of 400 costal strips in its lorica), and also by the presence in some species of an aggregated pedicel ( $S$. cauliculata Leadbeater, 1980, and S. campanula (Kent, 1880)Boucaud-Camou, 1967). In some species, i.e. S. elegans (Norris, 1965)Throndsen, 1974, and S. supracostata Hara, 1996, the helical costal strip component, otherwise characterizing the posterior lorica chamber, is no longer present. The generic type species, $S$. ampulla (Kent, 1880)Ellis, 1929, is only known from light microscopical studies and hence inadequately defined. Phylogenetic studies (e.g. Nitsche et al., 2011, 2017) have further clearly documented that the genus Stephanoeca is paraphyletic with species distributed within well separated clusters of the Stephanoecidae. Very recently it has been documented (Schiwitza et al., 2018) that a Stephanoeca like morphological appearance is also associated with a species (Enibas tolerabilis Schiwitza, Arndt and Nitsche, 2018) that has nudiform division and phylogenetically clusters within the family Acanthoecidae. Schiwitza et al. (2018) appropriately discusses the possibility that this may point to that the Stephanoeca-like lorica form is an ancestral type of lorica within the Acanthoecida. Given that we now know that a species with a Stephanoeca- 
like lorica has been shown to be nudiform, it appears relevant to tabulate across species of Stephanoeca the current status with respect to actual verification of tectiform division (Table 3). Molecular evidence is thus provided for a total of 6 species, while accumulations of newly formed costal strips in the collar region have been observed microscopically in 9 species. The mode of division is not known in 11 species including two of the species described here. It is important here to also emphasize that a nudiform 'behaviour' of siliconstarved S. diplocostata cells has been repeatedly observed following silicon replenishment and is thoroughly reported by Leadbeater (2015, loc. cit. chapter 8$)$.

During this survey we have come across six species of Stephanoeca, three of which are described as new species. While the new species described are morphologically unambiguously defined across the entire catalogue of loricate choanoflagellate species, it is also self-evident from the above that their allocation to the genus Stephanoeca will in all likelihood only be temporary.

S. supracostata Hara, 1996 in Hara et al., 1996 (Fig. 7a-b)

This species was described from coastal waters of Taiwan and Japan at water temperatures ranging between $18.8-26.8^{\circ} \mathrm{C}$ (Hara et al., 1996). It co-occurred with and is overall very similar to S. elegans. The main distinguishing feature is the presence in $S$. supracostata of an additional transverse costal ring in the anterior lorica chamber. In the Osaka Bay material S. elegans had 20-25 longitudinal costae while S. supracostata had only 14-18. Stephanoeca supracostata shares with S. elegans the absence of a helical costal element in the posterior lorica chamber and also the conspicuous spatulate tips of the anterior longitudinal costal strips (Fig. 7b).

Our material from the Andaman Sea (Fig. 7a-b) matches the Taiwanese type material in both morphological and dimensional features. The lorica height is $11-12 \mu \mathrm{m}$ which nicely (at $26-28^{\circ} \mathrm{C}$ ) fits the correlation matrix between water temperature and lorica height established by Hara at al. (1996). 
Stephanoeca supracostata is recorded from Taiwan and Japan (Hara et al., 1996), Southampton Water, UK (Tong, 1997a), Darwin, Australia (Lee et al., 2003), Rhode Island, USA (Menezes, 2005), Denmark (Thomsen, unpublished), and the Andaman Sea (Table 1).

\section{S. apheles Thomsen, 1991 in Thomsen et al., 1991 (Fig. 7c-g)}

The S. apheles specimens illustrated in Fig. 7c-g differ at the light microscopical level from S. supracostata (Fig. 7a-b) with reference to 1 ) the distance between the two anterior transverse costa (equal to the length of two longitudinal costal strips versus only 1.5 in S. supracostata), and 2) the presence of helical costal elements in the posterior lorica chamber. The West Australian specimens have 16-19 longitudinal costae and on overall lorica height that ranges between 16.5-18.5 $\mu \mathrm{m}$. The diameter at the opening of the anterior lorica chamber is ca. $7 \mu \mathrm{m}$ while the diameter at the level of the second transverse costa is 8-9.5 $\mu \mathrm{m}$. This agrees reasonably well with the Danish type material (Thomsen et al., 1991; lorica height: 13-16.5 $\mu \mathrm{m}$; 14-16 longitudinal costae; diam. at orifice: 3.8-4.8 $\mu \mathrm{m}$; diam. at the level of the second transverse costa: 5-7 $\mu \mathrm{m}$ ).

Stephanoeca apheles is recorded from Denmark and California (Thomsen et al., 1991), Taiwan and Japan (Hara et al., 1997), Finland (Ikävalko and Thomsen, 1997; Vørs, 1992), Gulf of St. Lawrence, Canada (BérardTherriault et al., 1999), West Greenland (Thomsen and Østergaard, 2017b), Patos Lagoon, southern Brazil (Bergesch et al., 2008), western Baltic Sea, Germany (Auer and Arndt, 2001), Rhode Island, USA (Menezes, 2005), and West Australia (Table 1). The distributional fingerprint of this taxon is that of a cosmopolitan species that has so far not been encountered in any high latitude cold water sample.

\section{S. diplocostata Ellis, 1929 var. paucicostata Throndsen, 1979 (Fig. 7h-j)}

This species is much similar to $S$. diplocostata but deviates by having fewer anterior lorica chamber transverse costae giving the anterior lorica chamber a more bulbous appearance. Lorica height is in our 
material (Fig. 7h-j) 12.5-13.5 $\mu \mathrm{m}$ and the maximum diameter approx. $10 \mu \mathrm{m}$, which is in good agreement with the Norwegian type material (Throndsen, 1969).

Stephanoeca diplocostata var. paucicostata (sometimes just referred to as S. paucicostata Throndsen, 1969) has a cosmopolitan distribution and is this far observed in samples from Mandal, Norway (Throndsen, 1969), Isefjord, Denmark (Thomsen, 1973), Tvärminne, Finland (Thomsen, 1979; Vørs, 1992), Tenerife, Spain (Vørs, 1993), Rhode Island, USA (Menezes, 2005), West Greenland (Thomsen, 1981, Thomsen and $\varnothing$ stergaard, 2017b), North East Water Polynya, Greenland (Thomsen and Østergaard, 2017b), East Australian Current (Hallegraeff, 1983), Shark Bay, Australia (Tong, 1997b), Sydney, Australia (Tong et al., 1998), California, USA (Thomsen et al., 1991), Japan and Taiwan (Hara et al., 1997), Prydz Bay, Antarctica (Marchant, 1985), Ellis Fjord, Antarctica (Marchant et al., 1987), Davis, Antarctica (Marchant and Perrin, 1990), Weddell Sea, Antarctica (Buck et al., 1990), and West Australia (Table 1).

\section{S. andemanica sp. nov. (Fig. 8)}

Diagnosis: Lorica bell-shaped and 15-18 $\mu \mathrm{m}$ high. A distinct waist separates the anterior and posterior lorica chambers. The protoplast is securely located in the posterior chamber while the collar of microvilli and the flagellum occupies space in the anterior chamber. There are 10 longitudinal costae and 3 transverse costae. Each longitudinal costa comprises 3 costal strips (6-7 $\mu \mathrm{m}$ long). The transverse costae are located at the junctions between the longitudinal costal strips and at the anterior lorica end forming a closure ring. Costal strips from the anterior ring are 4-5 $\mu \mathrm{m}$ long and each spans the distance between close to 1.5 longitudinal costae. There is thus a significant overlap between neighbouring transverse costal strips. The diameter at the lorica orifice is $9-10 \mu \mathrm{m}$. The anterior transverse ring is exterior to the longitudinal costae (Fig. 8i). Longitudinal costae are otherwise exterior to transverse elements (Fig. 8j). The diameter at the level of the second transverse costa is $10-11 \mu \mathrm{m}$. The increase in circumference is caused by a slightly diminished overlap between neighbouring costal strips. The waist diameter is 3.5-4.5 $\mu \mathrm{m}$. This reduction is achieved through a massive overlapping in multiple layers of neighbouring costal strips. The posterior conical lorica chamber 
comprises a few costal strips in addition to those that terminate the longitudinal costae. The helical costal component is thus much reduced and comprising just a couple of costal strips. A pedicel is not present, but a couple of costal strips frequently extend beyond the posterior tip of the lorica. Division mode uncertain.

Holotype: Fig. 8a from the Andaman Sea (Ao Patong, Phuket Island / 2 meters depth / ca. $28^{\circ} \mathrm{C}$ and a salinity of 35) collected $8^{\text {th }}$ Sept. 1981.

Etymology: The species name 'andemanica' is chosen to acknowledge that this species was first observed in samples from the Andaman Sea.

When thoroughly comparing Fig. $8 \mathrm{a}$ and Fig. $8 \mathrm{~b}$ it becomes evident that the pattern of transverse costal strip overlapping and positioning is different. One image is as a matter of fact a mirror image of the other. The major overlap between neighbouring anterior costal strips is to the right when the lorica is viewed from the outside in Fig. 8a,i (arrows) and to the left in Fig. 8b (arrows). The most likely explanation behind this phenomenon would be that an error was introduced while scanning the TEM negatives. However, this has been double checked, and the conclusion that stands is that the differences noted are genuine. Five additional specimens have been examined, and in four of these the pattern is similar to that observed in Fig. 8a. However, a single specimen is similar to Fig. 8 b. It has been well documented (Leadbeater 2015) that lorica construction, e.g. the formation of costae, requires the sliding of costal strips against each other aided by a rotational movement of the cell, and further that a left-handed rotation during lorica construction is universally applicable. However, in order to produce loricae that are mirror images (e.g. Fig. 8a-b) the direction of rotation while assembling the lorica must have been opposite. The relevance and consequence of this observation is not clear for the moment.

Stephanoeca andemanica was abundantly present in samples from the Andaman Sea and West Australia (Table 1), but somewhat surprisingly absent from all other sites investigated. The allocation of this morphologically fairly simple species to Stephanoeca is justified based on overall lorica features and a close resemblance to in particular S. diplocostata var. paucicostata. It is worth emphasizing that the S. andemanica 
lorica is highly conservative with respect to overall morphology and dimensions. The number of longitudinal costae has thus been invariably 10 in all cells examined. The fact that it has not been possible to detect signs of tectiform division, i.e. an assemblage of bundles of newly produced costal strips in the collar region, is note-worthy considering the number of specimens that have been documented from LM.

\section{S. broomia sp. nov. (Fig. 9)}

Diagnosis: Lorica small (10-13 $\mu \mathrm{m}$ long), bell-shaped and comprising two lorica chambers separated by a waist. The small posterior lorica chamber secures the protoplast. There are invariably 8 longitudinal costae each comprising 3 costal strips (4-5 $\mu \mathrm{m}$ long). The 3 transverse costae (costal strip length: 2.5-3.5 $\mu \mathrm{m}$ ) are located at the anterior opening of the lorica, and at the joints between the longitudinal costal strips. The lorica diameter is 7-9 $\mu \mathrm{m}$ at the anterior lorica orifice, $7-8 \mu \mathrm{m}$ at the level of the middle transverse costa and 2.5-3.5 $\mu \mathrm{m}$ at the level of the posterior transverse costa. There is an indication of helical costal strip components in the posterior lorica chamber (Fig. 9g). The lorica is posteriorly terminated by a pedicel that is an irregular tuft of diverging single costal strips (i.e. a compound pedicel). An organic membrane surrounds the protoplast and reaches up to the level of the middle transverse costa. Division mode uncertain.

Holotype: Fig. 9a from the Andaman Sea (Ao Patong, Phuket Island / 2 meters depth / ca. $28^{\circ} \mathrm{C}$ and a salinity of 35) collected $8^{\text {th }}$ Sept. 1981.

Etymology: The species epithet 'broomia' is chosen to acknowledge that the vast majority of the specimens examined originate from the Galathea3 Broome transect (see Thomsen and Østergaard, 2018).

A large number of S. broomia specimens were found in samples from West Australia and thus co-occurring with S. andemanica (see above). However, these cells (Fig. 9b-g) are significantly smaller than S. andemanica cells, they have invariably 8 longitudinal costae (versus 10), a 'compound' pedicel, and an overall lorica shape that is much less bulbous than that of $S$. andemanica. The finding of a single empty lorica from the Andaman Sea (Fig. 9a) that is similar to the West Australian material, yet slightly smaller, has prompted us to describe 
this material under a separate heading. Stephanoeca broomia shares with S. andemanica basic features in costal strip patterns including the external position of the anterior transverse costa and the internal location of other transverse elements. Stephanoeca broomia represents a further step away from mainstream Stephanoeca design (if such a concept at all exists within a highly heterogenous and polyphyletic genus). However, the obvious morphological linkage to S. andemanica and hence further to e.g. a Stephanoeca core species such as S. diplocostata var. paucicostata, is our justification for here and now describing this new taxon under the Stephanoeca heading.

\section{S. naja sp. nov. (Fig. 10)}

Diagnosis: Lorica bell-shaped and 15-20 $\mu \mathrm{m}$ high. Anteriorly there are minute protruding spines. Posteriorly the lorica leads into an extended pedicel comprising several costal strips. The lorica is constructed from c. 17 longitudinal costae and four transverse costae pairwise separated by a single longitudinal costal strip. The lorica diameter is $17,14,12.5$ and $8 \mu \mathrm{m}$ respectively at the level of the transverse costae starting from the anterior lorica end. The longitudinal costal strips average $6 \mu \mathrm{m}$ in length. Transverse costal strips measure 4.5-5 $\mu \mathrm{m}$. While the two anterior tiers of longitudinal costal strips count approximately 17 costal strips, the stratum below includes approximately 26 longitudinal costal strips. The change in numbers is prompted by bifurcations of approximately half of the longitudinal costae (Fig. 10a, arrows). The protoplast is located posteriorly in the lorica and surrounded by an irregular meshwork of costal strips that includes costal strips forming spiralling lorica elements. Division is tectiform as verified from the presence of bundles of costal strips in the collar region (Fig. 10f).

Holotype: Fig. 10a from the equatorial Pacific and collected (surface sample) along $110^{\circ} \mathrm{W} / 10^{\circ} \mathrm{N}-8^{\circ} \mathrm{S}$. Approximated values for temperature and salinity (PSU) at the sampling site are $28^{\circ} \mathrm{C}$ and 35 respectively.

Etymology: From Greenlandic naja ("younger sister of a male"). The species is named in honour of Naja Vørs (1960-1994) who managed, even though she tragically died at an early age, to contribute significantly to heterotrophic flagellate research. The image chosen as the type micrograph was taken by Naja following her 
participation in the NOAA Spring 1992 Cruise to the equatorial Pacific during the EqPac Process Study as part of the Equatorial Pacific Ocean Climate Study/Joint Global Ocean Flux Studies (EPOCS/JGOFS) of NSF/NOAA (Murray et al., 1994).

The allocation to the genus Stephanoeca is justified because of the presence in S. naja of clearly defined anterior and posterior lorica chambers that are separated by a waist, and further by the overall complexity of the lorica in terms of e.g. number of longitudinal and transverse costae which matches what has so far been observed in other species of Stephanoeca.

Stephanoeca naja is widespread and has been observed in samples from the Andaman Sea, West Australia, the Sargasso Sea, the equatorial Pacific Ocean and the Gulf of California (Table 1).

\section{Author contributions}

Helge A. Thomsen (HAT) has undertaken a major part of the sampling activities and the subsequent microscopical analyses. HAT is further responsible for compiling and writing the paper. Jette B. $\emptyset$ stergaard (JBO) has been much involved in the Andaman Sea and the Pacific Ocean sampling. JBO has also carried out the transmission electron microscopical examination of these samples.

\section{Acknowledgements}

Crew and scientists on board the research vessels ('Dana', 'Vaedderen', 'Chakratong Tongyia', 'Malcolm Baldrige') are acknowledged for good collaborative spirit and for providing excellent facilities for collecting and processing our samples. Dr. Gunni $Æ$ Ertebjerg and Steffen Mariager Pedersen are acknowledged for providing the samples from outside the Alexandria Harbour. We are grateful to Dr. Sergio Sanudo-Wilhelmy and Kurt Buck for organizing the trip to Gulf of California. Carol Kosman is warmly acknowledged for her 
meticulous contribution to this paper. Two anonymous reviewers are acknowledged for important contributions to this paper. Main funding sources, i.e. the Independent Research Fund Denmark, the Carlsberg Foundation, Danida (Denmark's development cooperation), the Højgaard Foundation, and the Danish Centre for Marine Research are acknowledged for their generous contributions to our research. The present work was carried out as part of the Galathea3 expedition under the auspices of the Danish Expedition Foundation (Galathea3 contribution no. 125) and also as part of the Sargasso-Eel 2014 Expedition. 


\section{References}

Auer, B., Arndt, H., 2001. Taxonomic composition and biomass of heterotrophic flagellates in relation to lake trophy and season. Freshw. Biol. 46, 959-972.

Bérard-Therriault, L., Poulin, M., Bossé, L., 1999. Guide d'identification du phytoplancton marin de l'estuaire et du Golfe du Saint-Laurent incluant également certains protozoaires. Publication Spéciale Canadienne des Sciences Halieutiques et Aquatiques 128, 1-387.

Bergesch, M., Odebrecht, C., Moestrup, $\varnothing$., 2008. Loricate choanoflagellates from the South Atlantic coastal zone $\left(\sim 32^{\circ} \mathrm{S}\right)$ including the description of Diplotheca tricyclica sp. nov. Biota Neotrop. 8, 111-122.

Buck, K.R., Marchant, H.J., Thomsen, H.A., Garrison, D.L. 1990. Kakoeca antarctica gen. et sp.n., a loricate choanoflagellate (Acanthoecidae, Choanoflagellida) from Antarctic sea ice with a unique protoplast suspensory membrane. Zool. Scr. 19, 389-394.

Carr, M., Leadbeater, B.S.C., Hassan, R., Nelson, M., Baldauf, S.L., 2008. Molecular phylogeny of choanoflagellates, the sister group to Metazoa. Proc. Natl Acad. Sci. USA 05, 16641-6. http://dx.doi.org/10.1073/pnas.0801667105

Ellis, W.N., 1929. Recent researches on the Choanoflagellata (Craspedomonadines). Annls. Soc. Royale Zool. Belgique 60, 49-88.

Espeland, G., Throndsen, J., 1986. Flagellates from Kilsfjorden, southern Norway, with description of two new species of Choanoflagellida. Sarsia 71, 209-226.

Hallegraeff, G.M., 1983. Scale-bearing and loricate nanoplankton from the East Australian Current. Bot. Mar. $26,493-515$.

Hara, S., Chen, Y.L., Sheu, J., Takahashi, E., 1996. Choanoflagellates (Sarcomastigophora, Protozoa) from the coastal waters of Taiwan and Japan. I. Three new species. J. Euk. Microbiol. 43, 136-143.

Hara, S., Sheu, J., Chen, Y.L., Takahashi, E., 1997. Choanoflagellates (Sarcomastigophora, Protozoa) from the coastal waters of Taiwan and Japan (II): Species composition and biogeography. Zool. Stud. 36, 98-110. 
Ikävalko, J., Thomsen, H.A., 1997. The Baltic sea ice biota (March 1994): A study of the protistan community. Europ. J. Protistol. 33, 229-243.

Leadbeater, B.S.C., 1972. Fine-structural observations on some marine choanoflagellates from the coast of Norway. J. Mar. Biol. Ass. U.K., 52, 67-79.

Leadbeater, B.S.C., 1973. External morphology of some marine choanoflagellates from the coast of Jugoslavia. Arch. Protistenk. 115, 234-252.

Leadbeater, B.S.C., 1974. Ultrastructural observations on nanoplankton collected from the coast of Jugoslavia and the Bay of Algiers. J. Mar. Biol. Assoc. U.K. 54, 179-196.

Leadbeater, B.S.C., 2015. The Choanoflagellates: Evolution, biology and ecology. Cambridge University Press. Leadbeater, B.S.C., Hassan, R., Nelson, M., Carr, M., Baldauf, S.L., 2008. A new genus, Helgoeca gen. nov., for a nudiform choanoflagellate. Europ. J. Protistol. 44, 227-237.

Lee, W.J., Brandt, S.M., Vørs, N., Patterson, D.J., 2003. Darwin's heterotrophic flagellates. Ophelia 57, 63-98. Marchant, H.J., 1985. Choanoflagellates in the Antarctic marine food chain. In: Siegfried, W.R., Condy, P.R., Laws, R.M. (Eds.), Antarctic nutrient cycles and food webs. Springer-Verlag, Berlin Heidelberg, pp. 271276.

Marchant, H.J., van den Hoff, J., Burton, H.R., 1987. Loricate choanoflagellates from Ellis Fjord, Antarctica including the description of Acanthocorbis tintinnabulum sp. nov. Proc. NIPR symp. Polar Biol. 1, 10-22.

Marchant, H.J., Perrin, R.A., 1990. Seasonal variation in abundance and species composition of choanoflagellates (Acanthoecidae) at Antarctic coastal sites. Polar Biol. 10, 499-505.

Menezes, S., 2005. Nanoplankton biodiversity in the Pettaquamscutt river estuary, Rhode Island, U.S.A. PhD thesis, Univ. Rhode Island, 319pp.

Moestrup, $\varnothing ., 1979$. Identification by electron microscopy of marine nanoplankton from New Zealand, including the description of four new species. New Zeal. J. Bot. 17, 61-95.

Moestrup, Ø., Thomsen, H.A., 1980. Preparation of shadow-cast whole mounts. In: Gantt, E. (Ed.), Handbook of Phycological methods. Vol. III. pp. 385-390 (Cambridge). 
Murray, J.W., Barber, R.T., Roman, M.R., Bacon, M.P., Feely, R.A., 1994. Physical and biological controls on carbon cycling in the equatorial Pacific. Science 266, 58-65.

Nielsen, T.G., Bjørnsen, P.K., Boonruang, P., Fryd, M., Hansen, P.J., Janekarn, V., Limtrakulvong, V., Munk, P., Hansen, O.S., Satapoomin, S., Sawangarreruks, S., Thomsen, H.A., Østergaard, J.B., 2004. Hydrography, bacteria and protist communities across the continental shelf and shelf slope of the Andaman Sea (NE Indian Ocean). Mar. Ecol. Prog. Ser. 274, 69-86.

Nitsche, F., 2014. Stephanoeca arndti spec. nov. - First cultivation success including molecular and autecological data from a freshwater acanthoecid choanoflagellate from Samoa. Europ. J. Protistol. 50, 412-421.

Nitsche, F., Carr, M., Arndt, H., Leadbeater, B.S.C., 2011. Higher level taxonomy and molecular phylogenetics of the Choanoflagellatea. J. Euk. Mikrobiol. 58, 452-462.

Nitsche, F., Thomsen, H.A., Richter, D.J., 2017. Bridging the gap between morphological species and molecular barcodes - exemplified by loricate choanoflagellates. Europ. J. Protistol. 57, 26-37.

Schiwitza, S., Arndt, H., Nitsche, F., 2018. First description of an euryoecious acanthoecid choanoflagellate species, Enibas tolerabilis gen. et sp. nov. from a salar in the Chilean Andes based on morphological and transcriptomic data. Europ. J. Protistol. (2018) https://doi.org/10.1016/j.ejop.2018.11.004

Takahashi, E., 1981. Floristic study of ice algae in the sea ice of a lagoon, Lake Saroma, Hokkaido, Japan. Mem. Natl. Inst. Pol. Res. (E) 34, 49-59.

Thomsen, H.A., 1973. Studies on marine choanoflagellates I. Silicified choanoflagellates of the Isefjord (Denmark). Ophelia 12, 1-26.

Thomsen, H.A., 1979. Electron microscopical observations on brackish-water nannoplankton from the Tvärminne area, SW coast of Finland. Acta Bot. Fennica 110, 11-37.

Thomsen, H.A., 1981. Planktonic choanoflagellates from Disko Bugt, West Greenland, with a survey of the marine nanoplankton of the area. Meddr Grønland, Biosci. 8, 35pp. 
Thomsen, H.A., 1992. Loricabærende choanoflagellater (Kraveflagellater). In: Thomsen, H.A. (Ed), Plankton I de indre danske farvande. Havforskning fra Miljøstyrelsen nr. 11, pp. 157.194.

Thomsen, H.A., Boonruang, P., 1983. A microscopical study of marine collared flagellates (Choanoflagellida) from the Andaman Sea, SW Thailand: Species of Stephanacantha gen. nov. and Platypleura gen. nov. Protistologica 19, 193-214.

Thomsen, H.A., Buck, K R., 1991. Choanoflagellate diversity with particular emphasis on the Acanthoecidae. In: Patterson, D.J., Larsen, J. (Eds.), Free-living heterotrophic flagellates. Clarendon Press, Oxford, pp. 259284.

Thomsen, H.A., Østergaard, J.B., 2017a. Circumstantial evidence of life history events in loricate choanoflagellates. Europ. J. Protistol. 58, 26-34.

Thomsen, H.A., Østergaard, J.B., 2017b. Acanthoecid choanoflagellates from the Atlantic Arctic region - a baseline study. Heliyon 3 (2017) e00345 doi: 10.1016/j.heliyon.2017. e00345

Thomsen, H.A., Østergaard, J.B., 2018. Loricate choanoflagellates (Acanthoecida) from warm water seas. I. Conioeca gen. nov. and Nannoeca Thomsen. Europ. J. Protistol. (2018) https://doi.org/10.1016/j.ejop.2018.11.001

Thomsen, H.A., Østergaard, J.B., 2019. Loricate choanoflagellates (Acanthoecida) from warm water seas. II. Bicosta Leadbeater, Apheloecion Thomsen, Campyloacantha Hara \& Takahashi and Saroeca Thomsen. Europ. J. Protistol., 67, 114-131.

Thomsen, H.A., Buck, K.R., Chavez, F.P., 1991. Choanoflagellates of the central California waters: taxonomy, morphology and species assemblages. Ophelia 33, 131-164.

Thomsen, H.A., Garrison, D.L., Kosman, C. 1997. Choanoflagellates (Acanthoecidae, Choanoflagellida) from the Weddell Sea, Antarctica, taxonomy and community structure with particular emphasis on the ice biota; with preliminary remarks on choanoflagellates from Arctic sea ice (Northeast Water Polynya, Greenland). Arch. Protistenkd. 14, 77-114. 
Thomsen, H.A., Nitsche, F., Richter, D.J., 2016. Seasonal occurrence of loricate choanoflagellates in Danish inner waters. Protist 167, 622-638.

Throndsen, J., 1969. Flagellates of Norwegian coastal waters. Norw. J. Bot. 16, 161-216.

Tong, S.M., 1997a. Choanoflagellates in Southampton Water including the description of three new species. J. Mar. Biol. Assoc. U.K. 77, 929-958.

Tong, S.M., 1997b. Heterotrophic flagellates from the water column in Shark Bay, Western Australia. Mar. Biol. 128, 517-536.

Tong, S.M., Nygaard, K., Bernard, C., Vørs, N., Patterson, D.J., 1998. Heterotrophic flagellates from the water column in Port Jackson, Sydney, Australia. Europ. J. Protistol. 34, 162-194.

Vørs, N., 1992. Heterotrophic amoebae, flagellates and heliozoa from the Tvärminne area, Gulf of Finland, in 1988-1990. Ophelia 36, 1-109.

Vørs, N., 1993. Marine heterotrophic amoebae, flagellates and heliozoa from Belize (Central America) and Tenerife (Canary Islands), with descriptions of new species, Luffisphaera bulbochaete n. sp., L. longihastis n. sp., L. turriformis n. sp. and Paulinella intermedia n. sp. J. Euk. Microbiol. 40, 272-287. 


\section{Figure legends}

Fig. 1. Map showing the approximate sampling sites for material reported here and MODIS sea surface temperatures (2003-2011 average/ source: earthobservatory.nasa.gov). A circle refers to a single spot sampling, while a line or square indicates that samples were collected along extended transects (for further information see the materials and methods section in Thomsen and Østergaard (2018)).

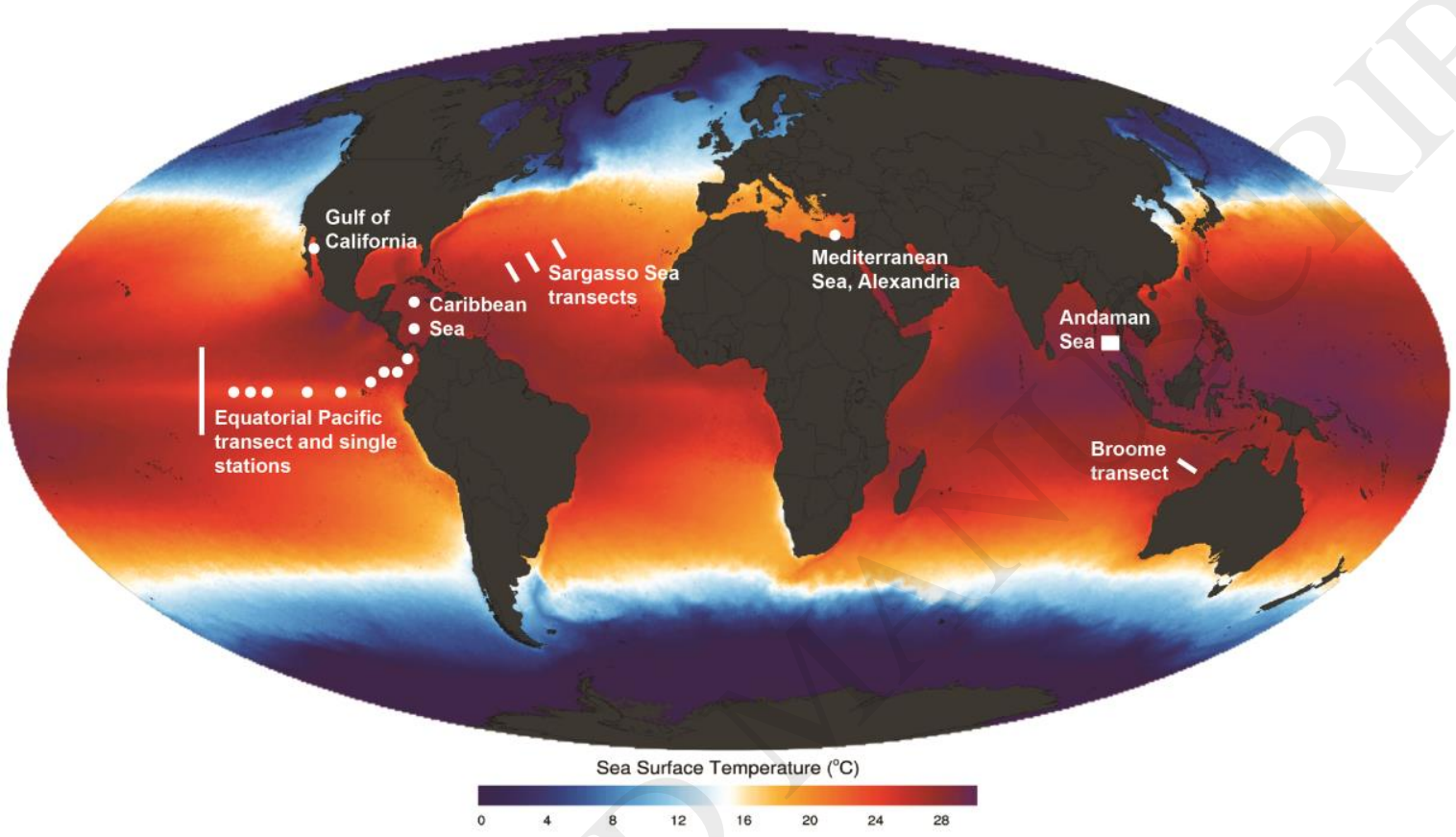

Fig. 2. Acanthocorbis spp. LM (e-m; phase contrast except m) and TEM (Fig. 2a-d) whole mounts from the Gulf of California, Mexico (Fig. 2a-h), West Australia (Fig. 2i-I), and the Andaman Sea, Thailand (Fig. 2m). Acanthocorbis apoda (Fig. 2a), A. conicella sp. nov. (Fig. 2b-I), and A. camarensis (Fig. 2m). (a) Empty lorica showing constructional features; (b) The lorica lining membrane is best visible in the areas pointed out. (c-d) Images showing various aspects of lorica features; (e-I) Specimens displaying the variability encountered in LM preparations; $(\mathrm{m})$ Complete cell (Nomarski contrast).

Scale bar (e) applies to all LM micrographs. 

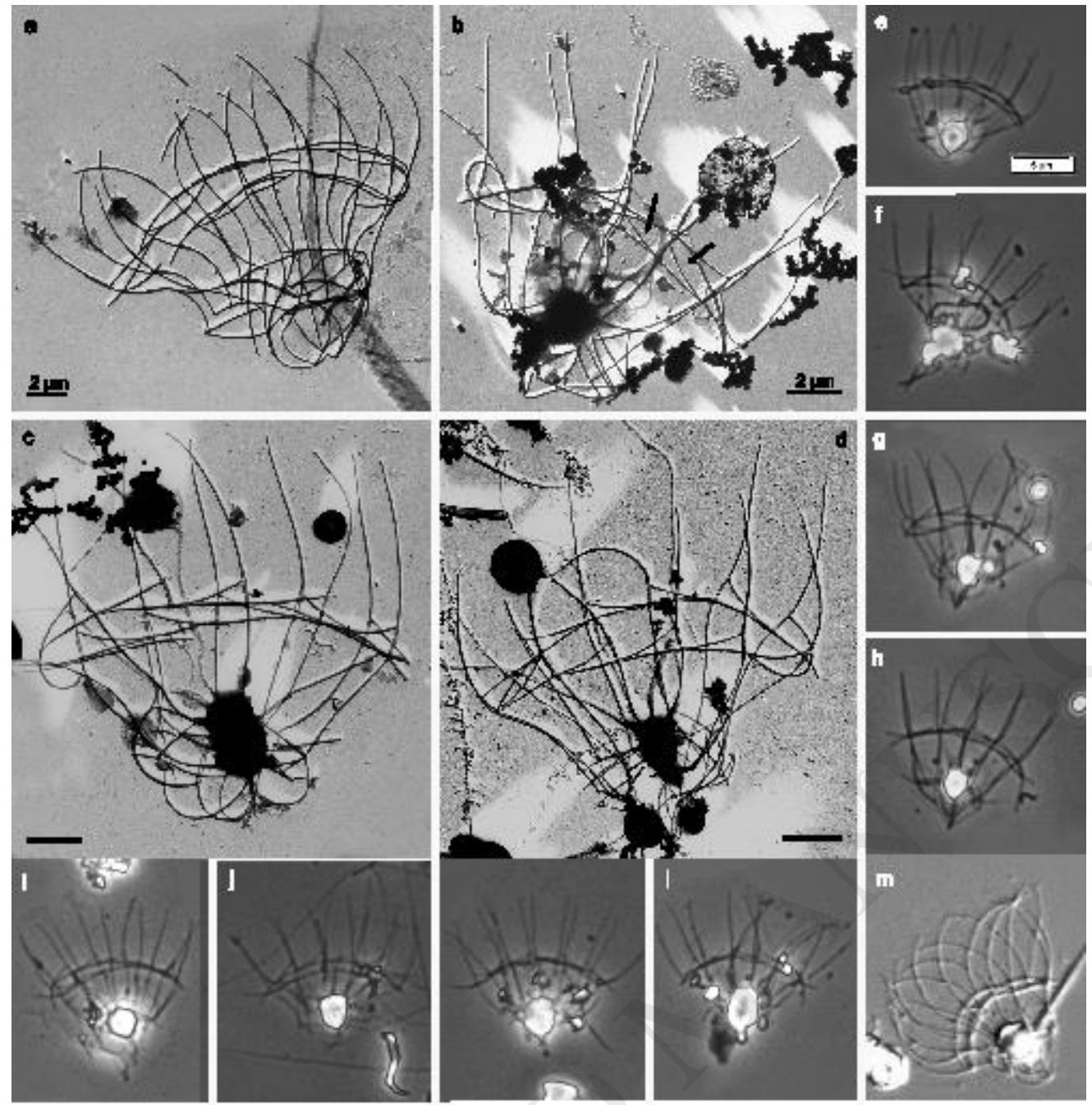

Fig. 3. Acanthocorbis campanula LM (d,g-j; phase contrast) and TEM whole mounts (a-c,e-f) from the Andaman Sea (a-c,e-f), West Australia (d,g-i) and the Sargasso Sea (j). (a) Complete cell; notice that the projections are longer than one costal strip; (b) Empty lorica; spines are equal in length to one costal strip; (c) Nail-like termination of the anterior spines; (d) Specimen with bundles of costal strips in the collar region and preparing for cell division; (e) Empty lorica partly concealed by large bacteria; (f) Complete cell; (g-j) Selection of LM images. 
The scalebar (g) applies to all LM micrographs.
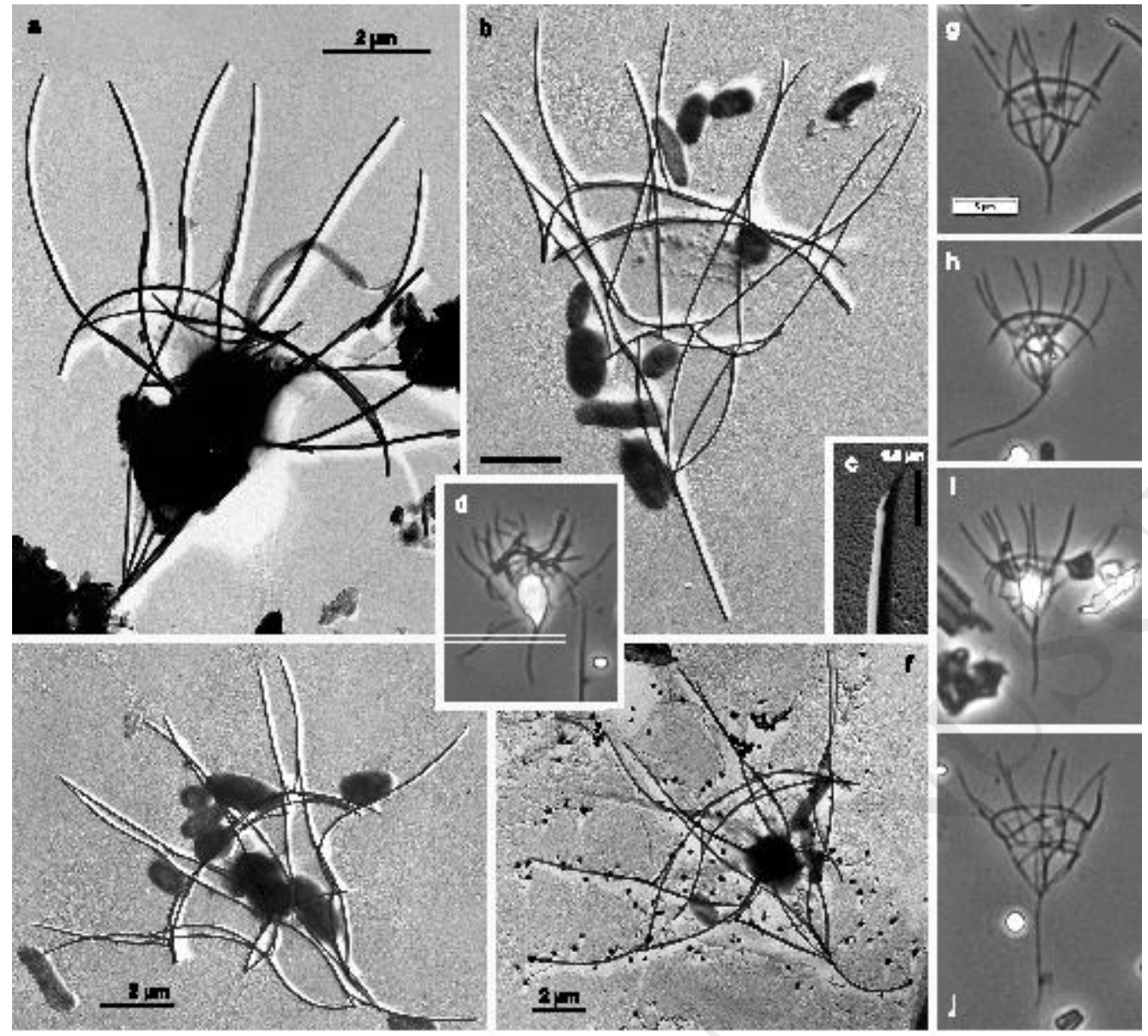

Fig. 4. Acanthocorbis haurakiana LM (c-h; phase contrast except Fig. 3c (Nomarski contrast)) and TEM whole mounts (Fig. 3a-b) from the Andaman Sea (a-c), the equatorial Pacific (d), and West Australia (e-h). (a) Complete cell; (b) Detail of lorica chamber; (c-h) Selection of LM images; the basket-like configuration of the posterior lorica chamber is evident from e-f.

The scale bar (c) applies to all LM micrographs. 


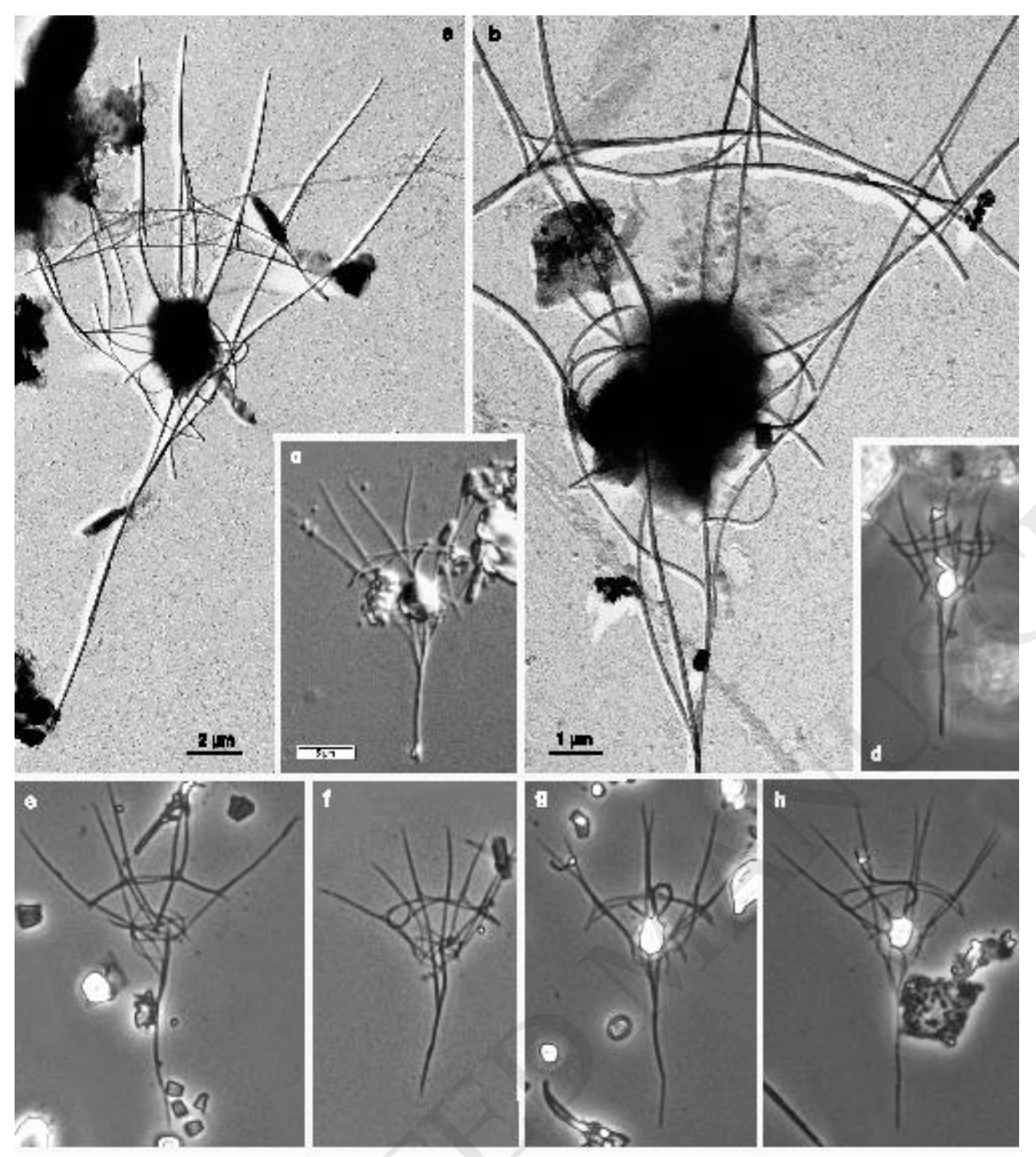

Fig. 5. Acanthocorbis gladiella sp. nov. TEM (a-e) and LM (f-i) whole mounts from the Andaman Sea (a-e), West Australia (f), the Sargasso Sea (g), the Caribbean Sea (h) and the equatorial Pacific Ocean (i). (a) Detail (reverse printing) of anterior spine (from Fig. 5c); (b) Empty lorica (type specimen); (c) Complete cell; (d) Detail of lorica chamber; notice the membrane (arrow) that reaches up to the anterior transverse costa; (e) Detail (reverse printing) from Fig. $5 d$ of anterior transverse costal strips carrying 'waves' of material; (f-i) Selected LM images. 
The scale bar (f) applies to all LM micrographs.

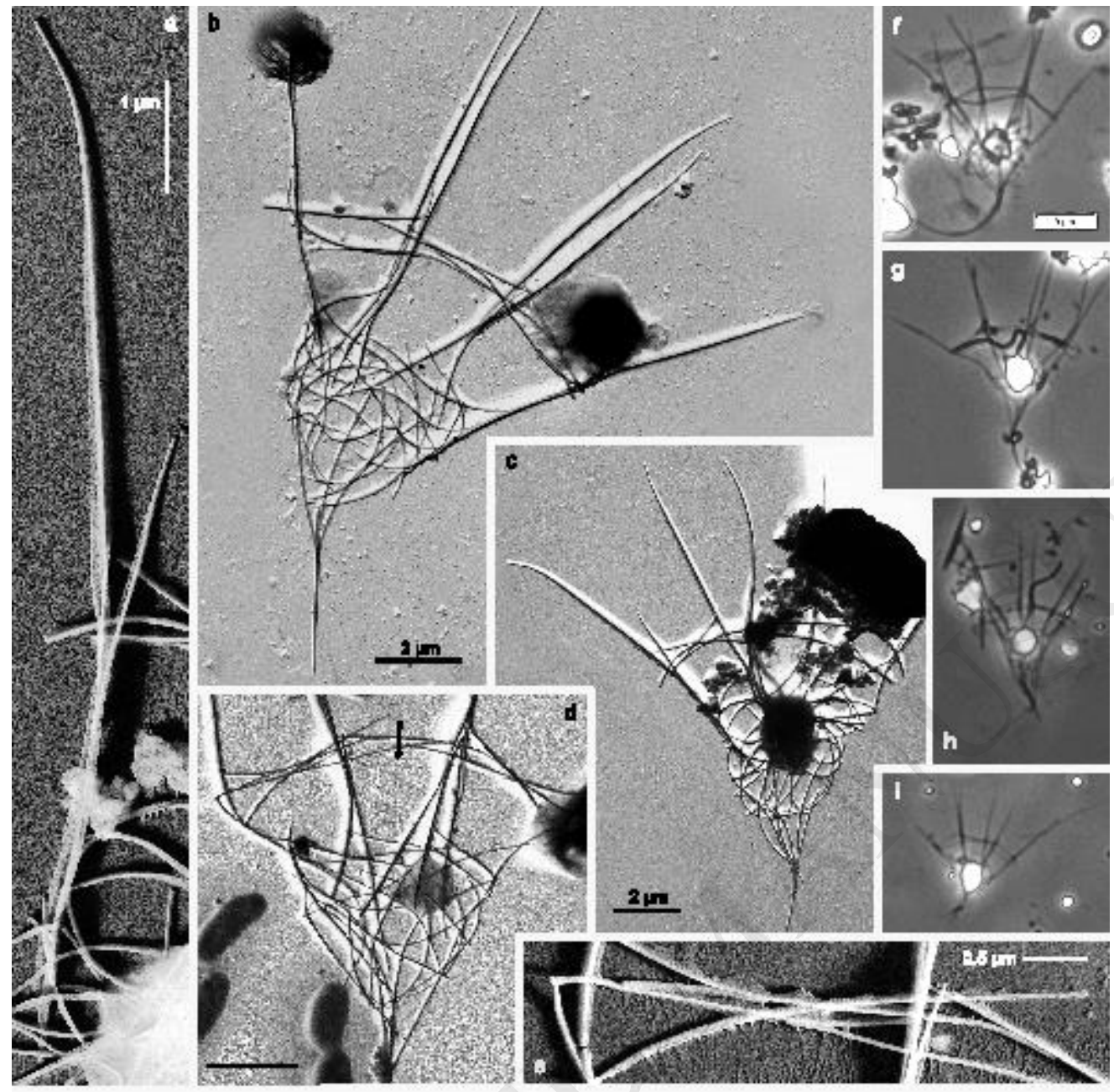

Fig. 6. Acanthocorbis gladiella sp. nov. TEM whole mounts from the Andaman Sea. (a) Detail of the anterior transverse costa lorica region (the transverse costa is in a vertical position). Notice the termination (arrows) of the anterior longitudinal costal strips, the longitudinal laminae attached (3-sided) to the anterior longitudinal costal strips (i.e. two flanges in the plane of the image (white arrowheads) and one flange that comes out of the image (black arrowhead)), and the irregular material piling up on the anterior edge of 
transverse costal strips; (b) Detail of posterior lorica chamber (from Fig. 5b) showing the flattened an irregular costal strips found here.
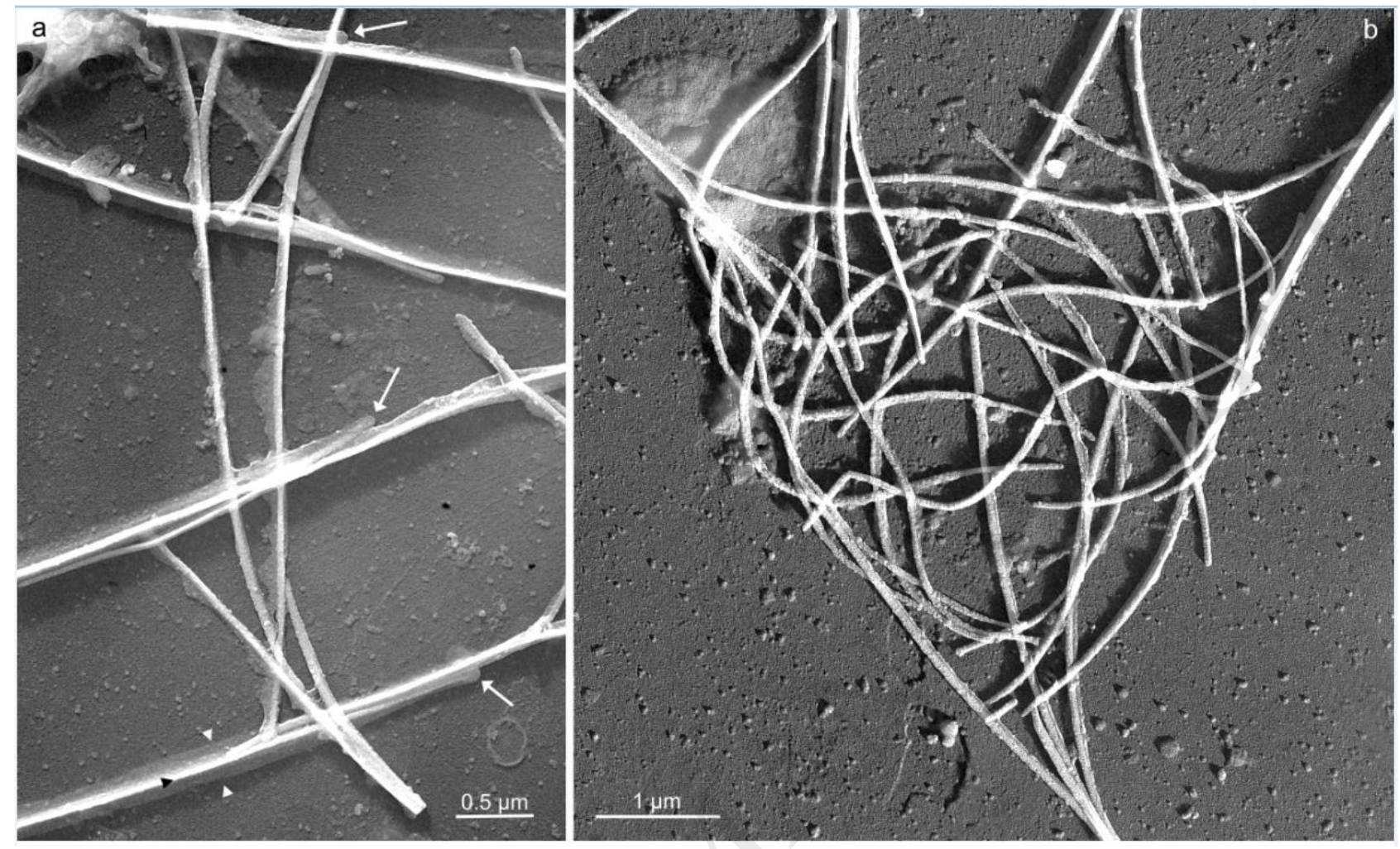

Fig. 7. Stephanoeca spp. TEM (a-b) and LM (c-j) whole mounts from the Andaman Sea (a-b) and West Australia (c-j). Stephanoeca supracostata (a-b), S. apheles (c-g), and S. diplocostata var. paucicostata (h-j). (a) Complete cell; notice that the posterior chamber is comprising longitudinal costal strips only; (b) Anterior lorica end of specimen showing the spatulate tips of anterior longitudinal costal strips; (c-g) Selected images to display the morphological uniformity; (h-j) Two complete specimens and one empty lorica.

The scale bar (d) applies to all LM micrographs. 


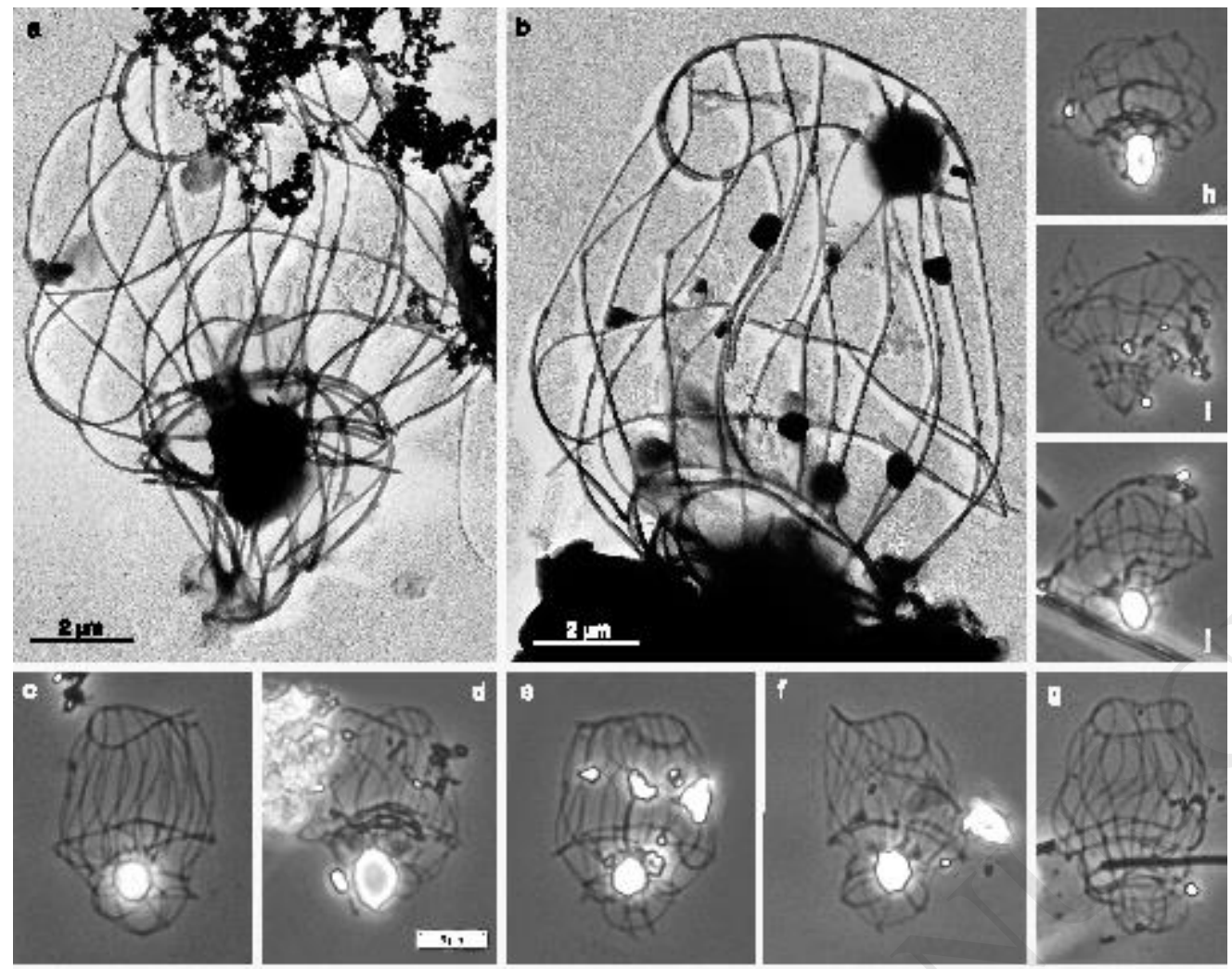

Fig. 8. Stephanoeca andemanica sp. nov. TEM (a-b,i-j) and LM (c-h) whole mounts from the Andaman Sea (ac,i-j) and West Australia (d-h). (a-b) Empty loricae (a: type specimen) showing the simplicity in lorica design which characterizes this species; (c-h) Selected images to show the variability in appearance of this taxon; (i) Detail from Fig. 8a to show the exterior location of the anterior transverse costa; (j) Detail from Fig. 8a showing the interiorly located middle transverse costa. See text for an explanation of arrows $(b, i)$. The scale bar (d) applies to all LM micrographs. 


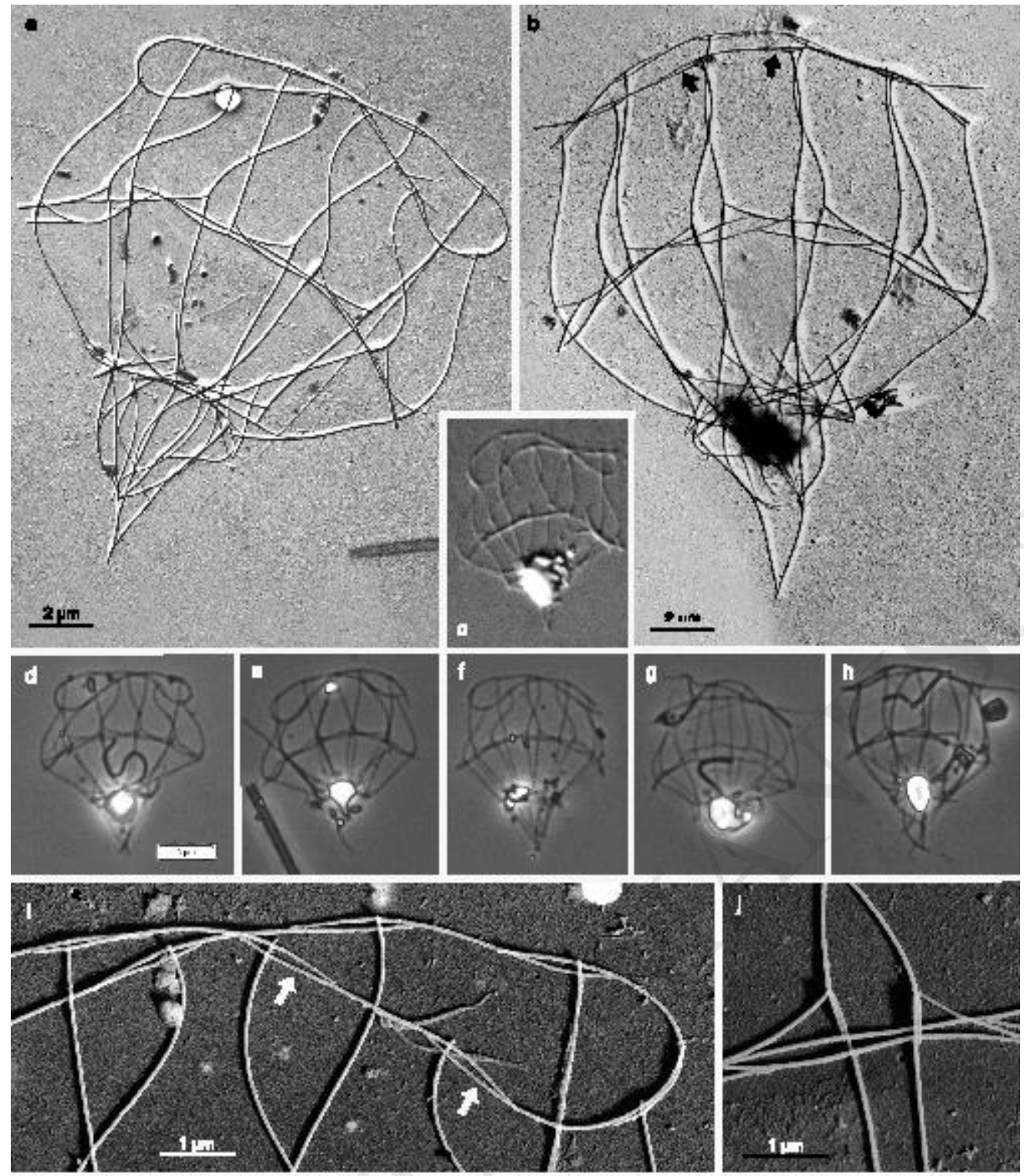

Fig. 9. Stephanoeca broomia sp. nov. TEM (a) and LM (b-g) whole mounts from the Andaman Sea (a) and West Australia (b-g). (a) Empty lorica (type specimen); the arrow points to a lorica 'window' where the membrane is particularly evident; (b-g) Selection of cells to show the overall variability encountered.

Scale bar (c) applies to all light micrographs. 


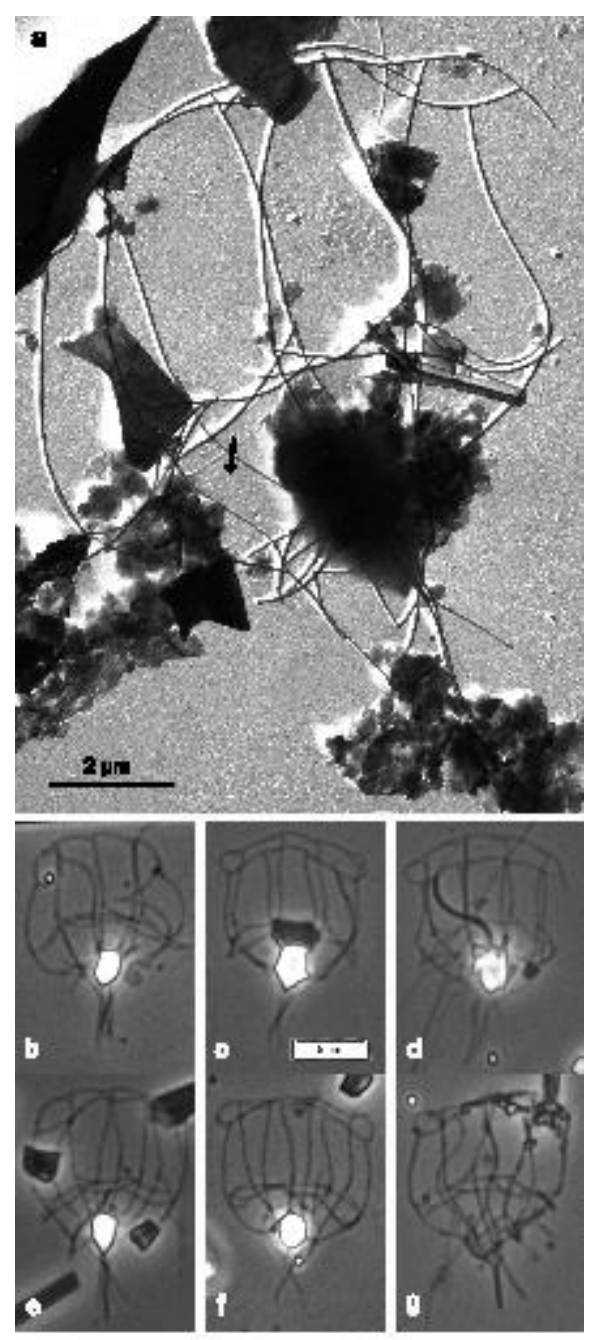

Fig. 10. Stephanoeca naja sp. nov. TEM (a) and LM (b-j) whole mounts from the equatorial Pacific Ocean (a, g-j), the Sargasso Sea (b), West Australia (c, f), and the Gulf of California (d), . (a) Partly empty lorica displaying details of its design (type specimen); arrows point to bifurcations of longitudinal costae; (b-j) Selected specimens from several geographic sites showing the overall variability encountered; notice the accumulation of bundles of costal strips in the collar region (f).

The scale bar ( $h$ ) applies to all LM micrographs. 


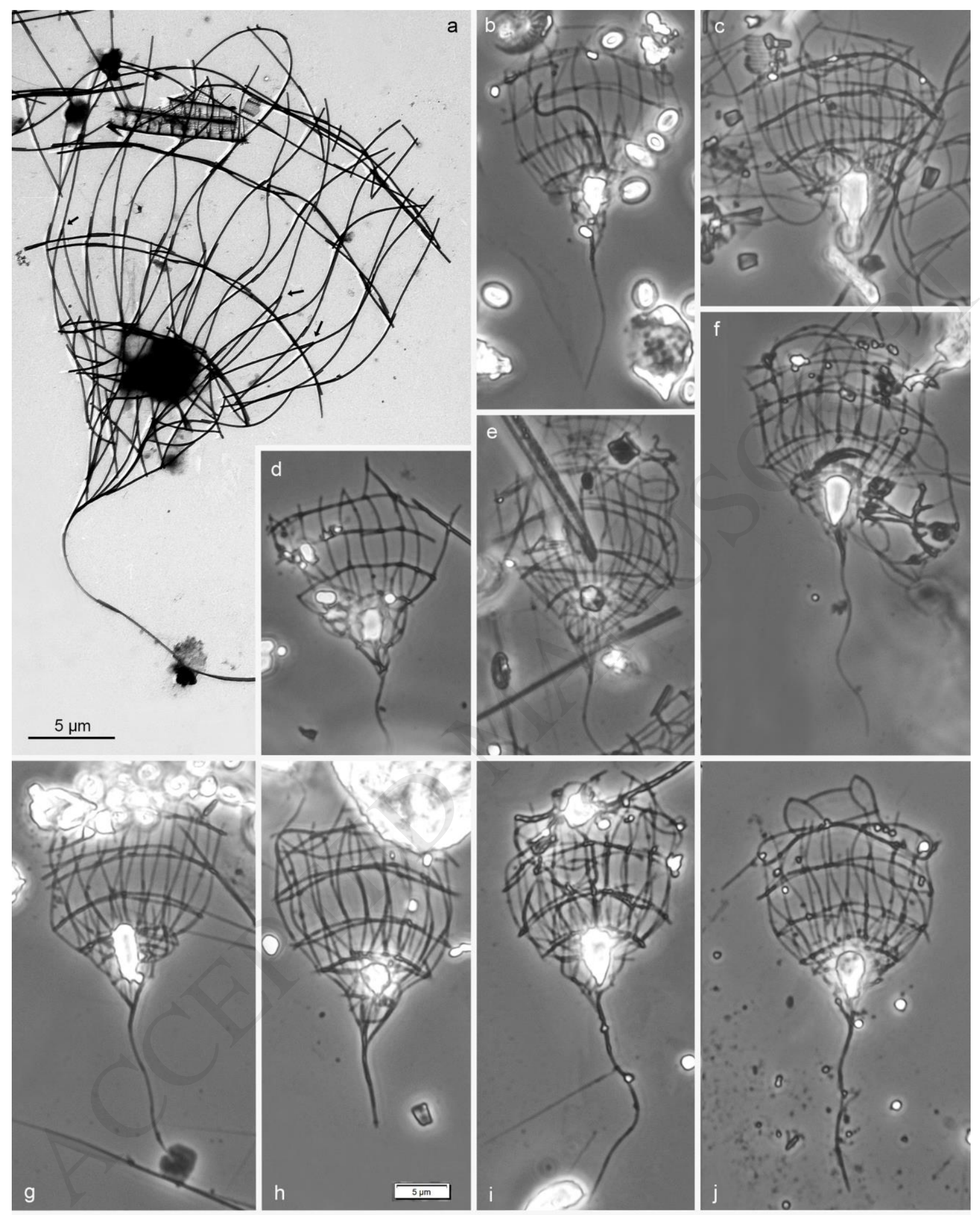


Table 1. Occurrence pattern of species discussed here and (shaded entries) in Thomsen and $\varnothing$ stergaard $(2018,2019)$. New species described here and in Thomsen and Østergaard $(2018,2019)$ are marked with *. An $\mathrm{x}$ in brackets indicates that the recording is made with some degree of reservation (for further details see Thomsen and Østergaard (2019)).

\begin{tabular}{|c|c|c|c|c|c|c|c|}
\hline & 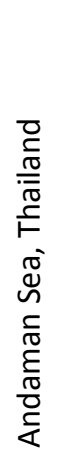 & 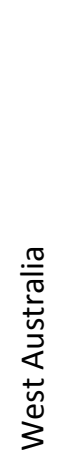 & 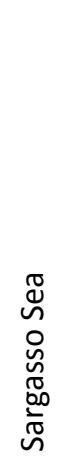 & 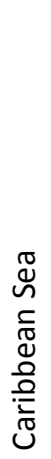 & 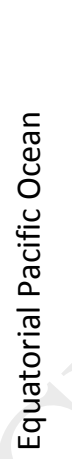 & 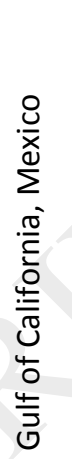 & 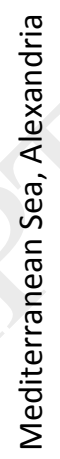 \\
\hline Acanthocorbis apoda & $x$ & & & & & & \\
\hline A. camarensis & $x$ & & & & & & \\
\hline A. campanula & $x$ & $x$ & $x$ & & & & \\
\hline A. conicella* & & $x$ & $x$ & & & $x$ & $x$ \\
\hline A. gladiella* & $x$ & $x$ & $\mathrm{x}$ & $x$ & $x$ & & \\
\hline A. haurakiana & $x$ & $x$ & $x$ & & & & \\
\hline Apheloecion articulatum & $x$ & $x$ & & & & & $x$ \\
\hline A. eqpacia* & $\mathrm{x}$ & $x$ & & & $x$ & & \\
\hline A. pentacanthum & $x$ & $x$ & & & $x$ & $x$ & $x$ \\
\hline A. quadrispinum & $x$ & $x$ & $x$ & $x$ & $x$ & & $x$ \\
\hline Bicosta minor (form A) & $x$ & $x$ & & $x$ & $\mathrm{x}$ & & \\
\hline B. spinifera & & & & & & $x$ & \\
\hline Campyloacantha imbricata & $x$ & $x$ & $x$ & $x$ & $x$ & & \\
\hline C. spinifera & $x$ & $x$ & $\mathrm{x}$ & & & $x$ & $x$ \\
\hline Calliacantha magna* & $\mathrm{x}$ & $x$ & & $\mathrm{x}$ & $\mathrm{x}$ & & \\
\hline C. natans & & & & & & $x$ & \\
\hline C. simplex & $x$ & $x$ & $\mathrm{x}$ & $x$ & $x$ & $x$ & $x$ \\
\hline Conioeca boonruangii* & $x$ & $x$ & & $x$ & $x$ & & \\
\hline Crucispina cruciformis & $x$ & $x$ & $x$ & & & $x$ & $x$ \\
\hline
\end{tabular}




\begin{tabular}{|l|c|c|c|c|c|c|c|}
\hline Nannoeca mexicana* & & $\mathrm{x}$ & & & $\mathrm{x}$ & \\
\hline N. minuta & $\mathrm{x}$ & $\mathrm{x}$ & $\mathrm{x}$ & $\mathrm{x}$ & $\mathrm{x}$ & $\mathrm{x}$ & $\mathrm{x}$ \\
\hline N. minuta (form A) & $\mathrm{x}$ & & & & $\mathrm{x}$ & & \\
\hline Saroeca attenuata & & & $\mathrm{x}$ & & $\mathrm{x})$ & & \\
\hline S. paucicostata & $\mathrm{x}$ & $\mathrm{x}$ & $\mathrm{x}$ & & & $\mathrm{x}$ & $\mathrm{x}$ \\
\hline Stephanoeca andemanica* & $\mathrm{x}$ & $\mathrm{x}$ & & & & & \\
\hline S. apheles & $\mathrm{x}$ & $\mathrm{x}$ & & & & & \\
\hline S. broomia* & $\mathrm{x}$ & $\mathrm{x}$ & & & & & \\
\hline S. diplocostata var. paucicostata & & $\mathrm{x}$ & & & & & \\
\hline S. naja* & $\mathrm{x}$ & $\mathrm{x}$ & $\mathrm{x}$ & & $\mathrm{x}$ & $\mathrm{x}$ & \\
\hline S. supracostata & $\mathrm{x}$ & & & & & & \\
\hline
\end{tabular}


Table 2: Morphometric characteristics of A. campanula (Kilsfjorden, Norway), A. campanula (Fig. 3) and A. conicella from the Gulf of California. All measurements are in $\mu \mathrm{m}$.

\begin{tabular}{|c|c|c|c|c|c|c|c|}
\hline Material & 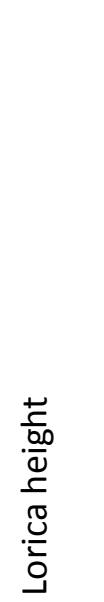 & 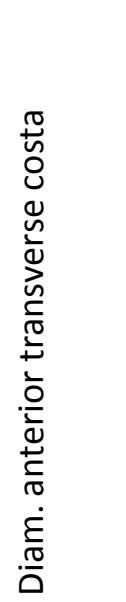 & 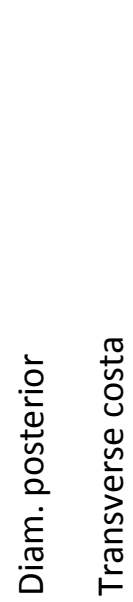 & 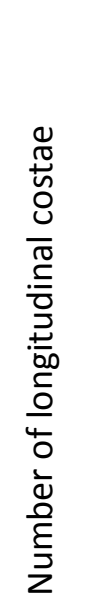 & 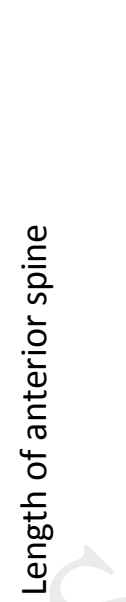 & 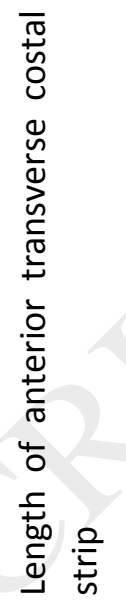 & \\
\hline $\begin{array}{lc}\text { A. campanula } & \text { type } \\
\text { material } & \text { from } \\
\text { Kilsfjorden, Norway }\end{array}$ & $9-18$ & $3.2-5.7$ & $2.2-4.1$ & $8-10$ & 3-5.5 & & $\begin{array}{l}\text { Data from } \\
\text { Espeland } \\
\text { and } \\
\text { Throndsen, } \\
1986\end{array}$ \\
\hline A. campanula (Fig.3) & $10-13$ & $5-8$ & $2.3-4$ & $7-9$ & $5-6$ & $3.5-4$ & $n=9$ \\
\hline $\begin{array}{l}\text { A. conicella sp. nov. } \\
\text { Gulf of California }\end{array}$ & $13-16$ & $8.3-10$ & $3.8-5.4$ & 11 & $6.2-7.8$ & $4.9-5.9$ & $\mathrm{n}=11$ \\
\hline
\end{tabular}


Table 3. Current status with reference to the verification of tectiform division in species of Stephanoeca as evidenced by molecular tools or visual identification by microscopy of bundles of supernumerary costal strips in the collar region.

\begin{tabular}{|c|c|c|}
\hline Species of Stephanoeca & $\begin{array}{l}\text { Tectiform division } \\
\text { verified using } \\
\text { molecular } \\
\text { techniques } \\
\end{array}$ & $\begin{array}{l}\text { Tectiform division verified from images showing an } \\
\text { accumulation of supernumerary costal strips in the } \\
\text { collar region }\end{array}$ \\
\hline S. ampulla (Kent, 1880)Ellis, 1929 & & Ellis, 1929 I.c. Fig. 12a \\
\hline \multicolumn{3}{|l|}{ S. andemanica sp. nov. } \\
\hline S. apheles Thomsen, 1991 in Thomsen et al., 1991 & Nitsche et al., 2011 & Fig. 7d (this paper) and Thomsen et al. 1991, I.c. Fig. 56 \\
\hline S. arndti Nitsche, 2014 & Nitsche, 2014 & \\
\hline \multicolumn{3}{|l|}{ S. broomia sp. nov. } \\
\hline \multicolumn{3}{|l|}{ S. campanula (Kent, 1880)Boucaud-Camou, 1967} \\
\hline S. cauliculata Leadbeater, 1980 & Nitsche et al., 2011 & \\
\hline \multicolumn{3}{|l|}{ S. complexa (Norris, 1965)Throndsen, 1974} \\
\hline \multicolumn{3}{|l|}{ S. constricta Ellis, 1929} \\
\hline \multicolumn{3}{|l|}{ S. cupula (Leadbeater, 1972)Thomsen, 1988} \\
\hline \multicolumn{3}{|l|}{ S. deminutiva (Norris, 1965)Throndsen 1974} \\
\hline S. diplocostata Ellis, 1929 & Carr et al., 2008 & Leadbeater, 1972 I.c. PI. VI D \\
\hline S. elegans (Norris, 1965)Throndsen, 1974 & & Leadbeater, 1972 I.c. PI. V E \\
\hline S. kenti Ellis, $1929{ }^{*} 1$ & & Ellis, 1929 I.c. Fig. 11a \\
\hline S. naja sp. nov. & & Fig. $10 f$ (this paper) \\
\hline S. norrisii Thomsen, $1973{ }^{*} 2$ & Nitsche et al., 2011 & Tong, 1997 I.c. Fig. 11B \\
\hline S. paucicostata Throndsen, $1969{ }^{* 3}$ & Nitsche et al., 2011 & $\begin{array}{l}\text { Thomsen (unpublished material from Denmark / neg.\# } \\
\text { T4528) }\end{array}$ \\
\hline \multicolumn{3}{|l|}{ S. pyxidoides Leadbeater, 1980} \\
\hline S. supracostata Hara, 1996 in Hara et al. 1976 & & Hara et al., 1996 I.c. Fig. 11 \\
\hline S. urnula Thomsen, 1973 & & \\
\hline
\end{tabular}


${ }^{* 1}$ Identical to Sportelloeca kentii (Ellis, 1929)Norris, 1965?

*2 syn: Sportelloeca kentii (Ellis, 1929)Norris, 1965

${ }^{* 3}=$ S. diplocostata var. paucicostata 